\title{
Genetic Diversity of Xanthomonas campestris pv. vitians, the Causal Agent of Bacterial Leafspot of Lettuce
}

\author{
Jeri D. Barak and Robert L. Gilbertson
}

Department of Plant Pathology, University of California, Davis 95616.

Accepted for publication 6 December 2002.

\begin{abstract}
Barak, J. D., and Gilbertson, R. L. 2003. Genetic diversity of Xanthomonas campestris pv. vitians, the causal agent of bacterial leafspot of lettuce. Phytopathology 93:596-603.

Bacterial leafspot of lettuce (BLS), caused by Xanthomonas campestris pv. vitians, has become more prevalent in many lettuce-growing areas of the world over the past decade. To gain insight into the nature of these outbreaks, the genetic variation in $X$. campestris pv. vitians strains from different geographical locations was examined. All strains were first tested for pathogenicity on lettuce plants, and then genetic diversity was assessed using (i) gas-chromatographic analysis of bacterial fatty acids, (ii) polymerase chain reaction analysis of repetitive DNA sequences (rep-PCR), (iii) DNA sequence analysis of the internal transcribed spacer region 1 (ITS1) of the ribosomal RNA, (iv) restriction fragment length polymorphism (RFLP) analysis of total genomic DNA

with a repetitive DNA probe, and (v) detection and partial characterization of plasmid DNA. Fatty acid analysis identified all pathogenic strains as X. campestris, but did not consistently identify all the strains as $X$. campestris pv. vitians. The rep-PCR fingerprints and ITS1 sequences of all pathogenic $X$. campestris pv. vitians strains examined were identi$\mathrm{cal}$, and distinct from those of the other $X$. campestris pathovars. Thus, these characteristics did not reveal genetic diversity among $X$. campestris pv. vitians strains, but did allow for differentiation of $X$. campestris pathovars. Genetic diversity among X. campestris pv. vitians strains was revealed by RFLP analysis with a repetitive DNA probe and by characterization of plasmid DNA. This diversity was greatest among strains from different geographical regions, although diversity among strains from the same location also was detected. The results of this study suggest that these $X$. campestris pv. vitians strains are not clonal, but comprise a relatively homogeneous group.
\end{abstract}

Over the past decade, outbreaks of bacterial leafspot (BLS) of lettuce, caused by Xanthomonas campestris pv. vitians, have occurred with increasing frequency throughout the world. Recent outbreaks have been reported from the United States (e.g., California [1], Florida [27], Hawaii [19], and Ohio [30]), Italy (43), Venezuela (9), Canada (6), and Turkey (29). Although $X$. campestris pv. vitians is widely distributed, little is known of the genetic diversity of this pathogen.

A number of approaches can be used to examine the genetic diversity of members of the genus Xanthomonas $(5,11,13,20,21,24$, $34,35,37-41)$. Vauterin et al. (39) analyzed protein electrophoresis patterns of 900 strains of $X$. campestris (Dye) and found that most, but not all, pathovars could be differentiated. Whereas most pathovars were comprised of a relatively homogeneous group of strains, some pathovars, including $X$. campestris pv. vitians, contained aberrant strains (39). Of the 10 strains of $X$. campestris pv. vitians from six countries (Colombia, Zimbabwe, United States, New Zealand, Brazil, and Australia) that were examined in this study, 8 had similar protein patterns, but the pathovar reference strain from Colombia (LMG 937) and a strain from Australia (LMG 8689) had patterns that clearly were distinct from each other and from those of the other $X$. campestris $\mathrm{pv}$. vitians strains. Stefani et al. (35) also used protein electrophoresis patterns to examine genetic diversity among strains of $X$. campestris pv. vitians and other $X$. campestris pathovars. In this study, the 21 strains of $X$. campestris pv. vitians examined (from New Zealand, United States, Brazil, Zimbabwe, and Italy) composed a fairly homogeneous group, despite their wide geographical distribution. The $X$. campestris pv. vitians strains also were differentiated from other pathovars including campestris, vesicatoria, pelargonii,

Corresponding author: R. L. Gilbertson; E-mail address: rlgilbertson@ucdavis.edu

Publication no. P-2003-0228-1R

(c) 2003 The American Phytopathological Society phaseoli, and juglandis, as well as Xanthomonas-like saprophytes recovered from lettuce. However, the pathovar reference strain (NCPPB 976=LMG 937) was considered to be aberrant based on having distinct colony morphology and protein pattern and, significantly, it was not pathogenic to lettuce (35).

Vauterin et al. (37) performed a comprehensive analysis of 183 strains of $X$. campestris using DNA hybridization data as well as other properties (phenotypic data from previous studies and metabolic activity on various carbon substrates), and proposed a new classification system for the genus Xanthomonas. On the basis of these analyses, it was concluded that $X$. campestris pv. vitians was a heterogeneous pathovar composed of two groups, type A and B. Type A included only the pathovar reference strain (LMG 937) and was named $X$. axonopodis pv. vitians. Type B contained all other strains, including LMG 8689 (previously reported to be an aberrant strain based on protein electrophoresis patterns) (39), and was named $X$. hortorum pv. vitians.

In the present study, the genetic diversity of $X$. campestris pv. vitians strains associated with recent BLS outbreaks of lettuce in California as well as those from a number of other geographical locations were examined. Five methods were used: (i) gas chromatographic (GLC) analysis of bacterial fatty acids, (ii) sequence analysis of the internal transcribed spacer region 1 (ITS1) of the ribosomal RNA, (iii) polymerase chain reaction analysis of repetitive DNA sequences (rep-PCR), (iv) restriction fragment length polymorphism (RFLP) analysis of total genomic bacterial DNA with a repetitive DNA probe, and (v) detection and partial characterization of plasmid DNA. The results of these analyses suggested that these strains compose a relatively homogeneous group, and did not reveal distinct groups or aberrant strains.

\section{MATERIALS AND METHODS}

Bacterial strains. The sources, year of isolation, and geographical origin of the strains $X$. campestris pv. vitians strains 
examined in this study are shown in Table 1 . Strains from California were isolated from lettuce plants with BLS symptoms or symptomless weeds growing near lettuce fields (1). One strain was recovered from a contaminated seed lot from an unknown location. Strains from other geographical locations were provided by other investigators or were obtained from the Laboratorium voor Microbiologie Gent Culture Collection (Gent, Belgium). All strains were subcultured by streaking on 523 medium (16), and single colonies were isolated. A single representative colony was selected, grown in yeast tryptone (YT) broth, and stored in $80 \%$ glycerol at $-80^{\circ} \mathrm{C}$. These frozen stock cultures served as sources of bacteria for subsequent experiments.

Pathogenicity tests. All putative strains of $X$. campestris pv. vitians were tested for pathogenicity on leaves of lettuce plants. Bacterial cells from a single colony of the strain to be tested were added to $2 \mathrm{ml}$ of YT broth in a 5-ml polypropylene tube (Fisher Scientific, Pittsburgh). Tubes were placed on a rotary shaker and cultures were grown for $30 \mathrm{~h}$ at $28^{\circ} \mathrm{C}$. Cultures were adjusted to an optical density of 0.4 at $600 \mathrm{~nm}$ (approximately $10^{8} \mathrm{CFU} / \mathrm{ml}$ ) and carborundum was added. The bacterial cell suspensions were rub inoculated with cotton swabs onto leaves of 3-week-old lettuce plants (cv. Salinas MI). The positive control was leaves inoculated with a California strain of $X$. campestris pv. vitians (strain Sal) (Table 1), whereas the negative control was leaves inoculated with sterile YT and carborundum. Plants were kept in a greenhouse maintained at approximately 28 to $30^{\circ} \mathrm{C}$, and examined 7 and 10 days postinoculation (dpi) for development of disease symptoms.

Fatty acid analysis. Strains of $X$. campestris pv. vitians used for fatty acid analyses (Table 1) were recovered from stock cultures by streaking onto 523 medium. Strains then were grown on trypticase soy broth agar (Fisher Scientific) for $24 \mathrm{~h}$ at $28^{\circ} \mathrm{C}$. Fatty acids were prepared according to the manufacturer's instructions, and whole cell fatty acid analysis was carried out by gas chromatography (26). Stenotrophomonas maltophilia was included as a positive control. Fatty acid profiles were determined for each strain and compared with available reference strains in the aerobe database of the Microbial Identification System (MIS) software package (version 3.8, September 1994 update; MIDI, Inc., Newark, DE).

Extraction of DNA. The strains used for rep-PCR, ITS1 sequence, and RFLP analyses are indicated in Table 1. Bacterial cells from a single colony were taken from a 24-h-old bacterial streak culture on 523 medium and added to $2 \mathrm{ml}$ of YT broth in a 5 -ml polypropylene tube. The tubes were placed on a rotary shaker and cultures were grown for $24 \mathrm{~h}$ at $28^{\circ} \mathrm{C}$. Nucleic acids were extracted from bacterial cells by the cetyltrimethylammonium bromide method $(17,31)$ and suspended in $100 \mu \mathrm{l}$ of sterile water. DNA concentrations were determined with a fluorometer (Model TKO 100; Hoefer Scientific Instruments, San Francisco). For PCR amplification of the ITS1 region and rep-PCR analyses, DNA was adjusted to a final concentration of $10 \mathrm{ng} / \mu \mathrm{l}$ with sterile water.

Rep-PCR. Rep-PCR was performed with the following primers: repetitive extragenic palindromic (REP)-PCR, $1 \mathrm{R}$ and 2I; enterobacterial repetitive intergenic consensus (ERIC)-PCR, 1R and 2; and BOX element 1A (BOX)-PCR, 1R (28). The PCR was carried out as described by Rademaker and de Bruijn (28) with $20 \mathrm{ng}$ of total genomic DNA. PCR was performed in a DNA Thermal Cycler 480 (Perkin-Elmer Cetus, Emeryville, CA), and PCR products were examined by electrophoresis in $0.7 \%$ agarose gels in $0.5 \times$ Tris-borate EDTA (TBE) buffer. Gels were stained with ethidium bromide and DNA was visualized with a gel imaging system.

PCR amplification and sequence analysis of the ITS1 region. The ITS1 rRNA spacer region, which lies between the $16 \mathrm{~S}$ and 23S rRNA genes, was amplified from $20 \mathrm{ng}$ of total genomic DNA by PCR with the G1/L1 primer pair (15). The PCR was per- formed in a GeneAmp 2400 (Perkin-Elmer Cetus), and PCR products were examined by electrophoresis in $1 \%$ agarose gels in Trisacetate EDTA (TAE) buffer. Gels were stained with ethidium bromide and DNA was visualized with a gel imaging system (Alpha Innotech Corp., San Leandro, CA). PCR-amplified DNA fragments were recovered using the QIAquick PCR Purification Kit (Qiagen, Valencia, CA) according to the manufacturer's recommendations.

PCR-amplified DNA fragments were sequenced directly using ABI PRISM Dye Terminator Cycle Sequencing with dRhodamine terminator chemistry. Sequencing reactions were fractionated in 5\% Long Ranger gels on an ABI PRISM 377 DNA Sequencer (Perkin-Elmer, Foster City, CA). Sequence data were analyzed using ABI Prism Á Sequencing 2.1.1 software (Perkin-Elmer Cetus) and DNA sequence comparisons were done with the software of the Genetics Computer Group, version 10, University of Wisconsin-Madison (10). The ITS1 sequences of strains of $X$. campestris were aligned using the Clustal W subprogram available in MacVector (version 7.1, 2001; Accelrys, Inc., Burlington, MA). Multiple alignment parameters were set to open, extended gap penalties were 2 and 1, respectively, and transitions were unweighted. No ambiguities were found in this alignment. The outgroup taxon, Xylella fastidiosa, was selected based on a BLAST search of the NCBI database using Xanthomonas campestris pv. vitians strain $\mathrm{Sal}$ as the template sequence. This search served to provide a taxon having the highest degree of sequence similarity outside the genus Xanthomonas. A non-Xanthomonas outgroup taxon was used to obtain a valid polarization of character traits in the phylogenetic analysis. The Xyella fastidiosa sequence was aligned to the Xanthomonas campestris alignment by hand based on secondary structure of rRNA (25).

Phylogenetic affiliations were inferred based on maximum parsimony using the computer program PAUP (version 4.0b10; Altivec) for the Macintosh (36). Parsimony analysis was conducted on informative characters using only a heuristic search having the random stepwise addition option. Gaps were set as missing data with transitions and transversion unweighted. Branch support was estimated by bootstrap analysis of 1,000 replications. Clade support was characterized using the computer program MacClade (version 3.05) to trace unambiguous synapomorphies (22).

RFLP analysis. Approximately $2 \mu \mathrm{g}$ of total genomic DNA was digested with EcoRI, BamHI, or HincII in a 50- $\mu$ l reaction (New England BioLabs, Beverly, MA). Digested DNA (approximately $1 \mu \mathrm{g}$ ) was fractionated in $0.7 \%$ agarose gels in $0.5 \times \mathrm{TBE}$ buffer, gels were stained with ethidium bromide, and DNA was visualized with a gel imaging system. DNA was transferred to Hybond-N+ nylon membranes (Amersham Pharmacia Biotech, Buckinghamshire, England) and hybridized with a repetitive probe as previously described $(12,31)$. The probe was the recombinant plasmid P2, which contains a 3.4-kb genomic DNA fragment from $X$. campestris pv. phaseoli (13), labeled with $\left[\alpha{ }^{-32} \mathrm{P}\right] \mathrm{dCTP}$ by nick translation (Life Technologies, Grand Island, NY). Membranes were hybridized with a probe activity of approximately 1.2 decays per minute $/ \mathrm{ml}$ of hybridization buffer. Hybridization was conducted in $30 \%$ formamide, $0.125 \mathrm{M} \mathrm{Na}_{2} \mathrm{HPO}_{4}(\mathrm{pH} 7.2), 2 \%$ sodium dodecyl sulfate (SDS), and $1 \mathrm{mM}$ EDTA (pH 8.0) overnight at $37^{\circ} \mathrm{C}$ in a hybridization oven (model HB-1D; Techne, Princeton, NJ). Membranes were washed twice in $0.125 \mathrm{M}$ $\mathrm{Na}_{2} \mathrm{HPO}_{4}(\mathrm{pH} 7.2), 1 \mathrm{mM}$ EDTA (pH 8.0), and $2 \%$ SDS at $42^{\circ} \mathrm{C}$ for $15 \mathrm{~min}$; and once in $0.0075 \mathrm{mM} \mathrm{Na} \mathrm{HPO}_{4}(\mathrm{pH} 7.2), 1 \mathrm{mM}$

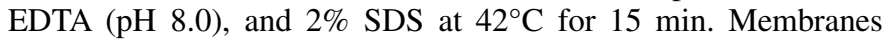
then were exposed to X-ray film (Fuji, Stamford, CT) for 12 and $24 \mathrm{~h}$.

Detection and analysis of plasmid DNA. Bacterial cells from a single colony were taken from a 24-h-old streak culture on 523 medium and added to $50 \mathrm{ml}$ of Luria broth in a 150-ml Erlenmeyer flask. Flasks were placed on a rotary shaker and cultures were grown for $24 \mathrm{~h}$ at $28^{\circ} \mathrm{C}$. Plasmid DNA was extracted from 
TABLE 1. Xanthomonas campestris strains used for fatty acid analysis, rDNA sequencing, polymerase chain reaction analysis of repetitive DNA sequences (rep-PCR), restriction fragment length polymorphism (RFLP) analysis, and plasmid profiling

\begin{tabular}{|c|c|c|c|c|c|c|c|c|}
\hline X. campestris strain & Year & Host & Geographical origin & Fatty acid & ITS $1^{\mathrm{a}}$ & rep-PCR & RFLP & Plasmid \\
\hline \multicolumn{9}{|l|}{ pv. vitians } \\
\hline Fl-1 & 1995 & Lactuca sativa & Florida & + & $\ldots$ & $\ldots$ & + & + \\
\hline 9301 & 1993 & Lactuca sativa & Gonzales, CA & + & $\ldots$ & $\ldots$ & $\ldots$ & $\ldots$ \\
\hline 9302 & 1993 & Lactuca sativa & Salinas, CA & + & $\ldots$ & + & $\ldots$ & $\ldots$ \\
\hline 9303 & 1993 & Lactuca sativa & Gonzales, CA & + & AF279425 & $\ldots$ & $\ldots$ & $\ldots$ \\
\hline 9304 & 1993 & Lactuca sativa & Chualar, CA & + & $\ldots$ & $\ldots$ & $\ldots$ & $\ldots$ \\
\hline 9305 & 1993 & Lactuca sativa & Guadalupe, CA & + & $\ldots$ & $\ldots$ & $\ldots$ & $\ldots$ \\
\hline 9306 & 1993 & Lactuca sativa & Salinas, CA & + & $\ldots$ & $\ldots$ & $\ldots$ & $\ldots$ \\
\hline 9307 & 1993 & Lactuca sativa & Salinas, CA & + & $\ldots$ & $\ldots$ & $\ldots$ & $\ldots$ \\
\hline 9308 & 1993 & Lactuca sativa & Gonzales, CA & + & $\ldots$ & + & $\ldots$ & $\ldots$ \\
\hline 9309 & 1993 & Lactuca sativa & Salinas, CA & + & $\ldots$ & $\ldots$ & $\ldots$ & $\ldots$ \\
\hline 9310 & 1993 & Lactuca sativa & Salinas, CA & $\ldots$ & $\ldots$ & + & $\ldots$ & $\ldots$ \\
\hline $\mathrm{H}+$ & 1995 & Seed & Unknown location & + & $\ldots$ & $\ldots$ & $\ldots$ & $\ldots$ \\
\hline 41335 & 1983 & Lactuca sativa & Australia & + & AF279426 & + & + & + \\
\hline 30547 & 1978 & Lactuca sativa & Pimlico, NSW, Australia & + & $\ldots$ & + & + & $\ldots$ \\
\hline 31975 & 1978 & Lactuca sativa & Dareton, NSW, Australia & + & $\ldots$ & + & + & + \\
\hline 30526 & 1978 & Lactuca sativa & Rydalmere, NSW, Australia & + & AF279427 & + & + & $\ldots$ \\
\hline $95-02$ & 1995 & Lactuca sativa & Watsonville, $\mathrm{Ca}$ & + & $\ldots$ & $\ldots$ & $\ldots$ & $\ldots$ \\
\hline Pyb251 & 1995 & Lactuca sativa & Monterey, CA & + & $\ldots$ & + & $\ldots$ & $\ldots$ \\
\hline Sal & 1995 & Lactuca sativa & Salinas, CA & + & AF279422 & + & + & + \\
\hline $\mathrm{KC}$ & 1995 & Lactuca sativa & King City, CA & + & $\ldots$ & $\ldots$ & $\ldots$ & $\ldots$ \\
\hline GON & 1995 & Lactuca sativa & Gonzales, CA & + & $\ldots$ & $\ldots$ & $\ldots$ & $\ldots$ \\
\hline 9401 & 1994 & Lactuca sativa & Salinas, CA & + & $\ldots$ & $\ldots$ & $\ldots$ & $\ldots$ \\
\hline B162 & 1995 & Lactuca sativa & Guadalupe, CA & + & AF279424 & $\ldots$ & + & + \\
\hline LL2 & 1995 & Lactuca sativa & Bakersfield, CA & + & AF279423 & $\ldots$ & + & + \\
\hline 9812 & 1998 & Lactuca sativa & Salinas, CA & $\ldots$ & $\ldots$ & + & $\ldots$ & $\ldots$ \\
\hline 9862 & 1998 & Senecio vulgaris & Salinas, CA & $\ldots$ & + & + & $\ldots$ & $\ldots$ \\
\hline 9868 & 1998 & Lactuca sativa & Salinas, CA & $\ldots$ & $\ldots$ & + & + & $\ldots$ \\
\hline 9873 & 1998 & Lactuca sativa & Salinas, CA & $\ldots$ & $\ldots$ & + & $\ldots$ & $\ldots$ \\
\hline 9879 & 1998 & Lactuca sativa & Salinas, CA & $\ldots$ & $\ldots$ & + & + & $\ldots$ \\
\hline 9813 & 1998 & Senecio vulgaris & Santa Maria, CA & $\ldots$ & $\ldots$ & + & $\ldots$ & $\ldots$ \\
\hline 9815 & 1998 & Malva parvilflora & Santa Maria, CA & $\ldots$ & + & + & $\ldots$ & $\ldots$ \\
\hline 9824 & 1998 & Sonchus oleraceus & Santa Maria, CA & $\ldots$ & + & + & + & + \\
\hline 9839 & 1998 & Lactuca sativa & Santa Maria, CA & $\ldots$ & $\ldots$ & + & $\ldots$ & $\ldots$ \\
\hline 9844 & 1998 & Lactuca sativa & Santa Maria, CA & $\ldots$ & $\ldots$ & + & + & \\
\hline 9832 & 1998 & Brassica rapa & Lompoc, CA & $\ldots$ & $\ldots$ & + & $\ldots$ & $\ldots$ \\
\hline 9828 & 1998 & Lupinus formosus & Lompoc, CA & $\ldots$ & $\ldots$ & + & $\ldots$ & $\ldots$ \\
\hline 9834 & 1998 & Malva parvilflora & Lompoc, CA & $\ldots$ & $\ldots$ & + & $\ldots$ & $\ldots$ \\
\hline 9851 & 1998 & Polygonum arenastrum & Lompoc, CA & $\ldots$ & + & + & + & $\ldots$ \\
\hline 9856 & 1998 & Lactuca sativa & Lompoc, CA & $\ldots$ & $\ldots$ & + & + & $\ldots$ \\
\hline 9906 & 1979 & Lactuca sativa & Kula, HI & $\ldots$ & $\ldots$ & + & $\ldots$ & $\ldots$ \\
\hline 9909 & 1979 & Lactuca sativa & Kula, HI & $\ldots$ & $\ldots$ & + & $\ldots$ & $\ldots$ \\
\hline 9910 & 1979 & Lactuca sativa & Kula, HI & $\ldots$ & $\ldots$ & + & $\ldots$ & $\ldots$ \\
\hline 9912 & 1979 & Lactuca sativa & Kula, HI & $\ldots$ & + & + & + & + \\
\hline 9915 & 1979 & Lactuca sativa & Kula, HI & $\ldots$ & + & $\ldots$ & $\ldots$ & $\ldots$ \\
\hline 9916 & 1979 & Lactuca sativa & Kula, HI & $\ldots$ & $\ldots$ & + & + & + \\
\hline 9918 & 1979 & Lactuca sativa & Kula, HI & $\ldots$ & $\ldots$ & + & $\ldots$ & $\ldots$ \\
\hline $\mathrm{LMG}^{\mathrm{b}} 937^{\mathrm{c}}$ & 1961 & Lactuca sativa & Columbia & $\ldots$ & + & + & $\ldots$ & $\ldots$ \\
\hline LMG 8689 & 1988 & Lactuca sativa & Australia & $\ldots$ & + & + & $\ldots$ & $\ldots$ \\
\hline pv. alfalfae & & & & $\ldots$ & $\ldots$ & $\ldots$ & $\ldots$ & $\ldots$ \\
\hline 101 & 1995 & Medicago sativa & California & $\ldots$ & $\ldots$ & + & $\ldots$ & $\ldots$ \\
\hline 102 & 1995 & Medicago sativa & California & $\ldots$ & $\ldots$ & + & $\ldots$ & $\ldots$ \\
\hline pv. armoraciae & & & & $\ldots$ & $\ldots$ & $\ldots$ & $\ldots$ & $\ldots$ \\
\hline 275 & 1992 & Brassica oleracea & California & $\ldots$ & $\ldots$ & + & $\ldots$ & $\ldots$ \\
\hline 756 & 1992 & Brassica oleracea & California & $\ldots$ & $\ldots$ & + & $\ldots$ & $\ldots$ \\
\hline pv. campestris & & & & $\ldots$ & $\ldots$ & $\ldots$ & $\ldots$ & $\ldots$ \\
\hline 295 & 1993 & Brassica oleracea & California & $\ldots$ & $\ldots$ & + & $\ldots$ & $\ldots$ \\
\hline 404 & 1994 & Brassica oleracea & California & $\ldots$ & $\ldots$ & + & $\ldots$ & $\ldots$ \\
\hline pv. carotae & & & & $\ldots$ & $\ldots$ & $\ldots$ & $\ldots$ & $\ldots$ \\
\hline 4 & 1994 & Daucus carota & Davis, CA & $\ldots$ & AF279430 & $\ldots$ & $\ldots$ & $\ldots$ \\
\hline 16 & 1995 & Daucus carota & Cuyama, CA & $\ldots$ & AF279428 & $\ldots$ & $\ldots$ & $\ldots$ \\
\hline 21 & 1995 & Daucus carota & Owens Valley, CA & $\ldots$ & AF279429 & $\ldots$ & $\ldots$ & $\ldots$ \\
\hline 9936 & 1999 & Daucus carota & Lancaster, CA & $\ldots$ & $\ldots$ & + & $\ldots$ & $\ldots$ \\
\hline 9940 & 1999 & Daucus carota & Lancaster, CA & $\ldots$ & $\ldots$ & + & $\ldots$ & $\ldots$ \\
\hline pv. phaseoli & & & & $\ldots$ & $\ldots$ & $\ldots$ & $\ldots$ & $\ldots$ \\
\hline 17 & 1997 & Phaseolus vulgaris & Malawi & $\ldots$ & AF279431 & $\ldots$ & $\ldots$ & $\ldots$ \\
\hline 20 & 1998 & Phaseolus vulgaris & Tanzania & $\ldots$ & AF279430 & $\ldots$ & $\ldots$ & $\ldots$ \\
\hline var. fuscans & & & & $\ldots$ & & $\ldots$ & $\ldots$ & $\ldots$ \\
\hline 12 & 1997 & Phaseolus vulgaris & Malawi & $\ldots$ & AF279433 & $\ldots$ & $\ldots$ & $\ldots$ \\
\hline 13 & 1997 & Phaseolus vulgaris & Malawi & $\ldots$ & & + & $\ldots$ & $\ldots$ \\
\hline 16 & 1997 & Phaseolus vulgaris & Malawi & $\ldots$ & AF279434 & $\ldots$ & $\ldots$ & $\ldots$ \\
\hline 54 & 1987 & Phaseolus vulgaris & Brazil & $\ldots$ & $\ldots$ & + & $\ldots$ & $\ldots$ \\
\hline
\end{tabular}

${ }^{\mathrm{a}}$ ITS = internal transcribed spacer region 1 sequence; accession numbers for sequences deposited in the GeneBank.

${ }^{\mathrm{b}} \mathrm{LMG}=$ Culture Collection, Laboratorium voor Microbiologie, Gent, Belgium; + indicates that a strain was used for this analysis.

${ }^{c}$ Pathovar reference strain. 
bacterial cells with the Qiagen Plasmid Midi Kit (Qiagen, Valencia, CA). Plasmid DNA was analyzed by agarose gel (0.5\%) electrophoresis in $0.5 \%$ TAE, and the concentration of each plasmid DNA preparation was determined with a fluorometer. Approximately $100 \mathrm{ng}$ of plasmid DNA was digested with EcoRI, BamHI, or SmaI in a 25- $\mu$ reaction (New England BioLabs, Beverly, MA). Digested plasmid DNA was analyzed by agarose gel electrophoresis in $0.5 \%$ gels in $0.5 \times$ TBE buffer. Gels were stained with ethidium bromide and DNA was visualized with a gel imaging system.

\section{RESULTS}

Pathogenicity tests. Strains of $X$. campestris pv. vitians induced dark, brown-black watersoaked lesions with yellow margins on inoculated lettuce leaves approximately 7 to $10 \mathrm{dpi}$. Pathogenic strains of $X$. campestris pv. vitians were recovered from lettuce leaves with BLS symptoms, from leaves of symptomless weeds from various locations in California, and from a contaminated seed lot. Additional pathogenic strains were obtained from Florida, Hawaii, and Australia (Table 1). Symptoms induced by all of these strains were similar to those produced by a known strain of $X$. campestris pv. vitians (strain Sal). Leaves of control plants inoculated with sterile YT medium and carborundum did not develop symptoms.

Two $X$. campestris pv. vitians strains were obtained from the Laboratorium voor Microbiologie Gent Culture Collection (LMG 937 and 8689). Strain LMG 937 represented the type A $X$. campestris pv. vitians strains that were renamed $X$. axonopodis $\mathrm{pv}$. vitians, whereas strain LMG 8689 represented the type B strains that were renamed $X$. hortorum pv. vitians (37). Neither strain induced disease symptoms in inoculated lettuce leaves in three independent experiments. In addition, both of these strains were morphologically distinct from the other strains of $X$. campestris pv. vitians examined in this study, which were yellow and mucoid. LMG 937 was yellow but nonmucoid, whereas LMG 8689 was white and mucoid.

Fatty acid analysis. Three independent whole-cell fatty acid analyses were conducted with 24 pathogenic $X$. campestris pv. vitians strains (Table 1). The fatty acid profiles of $S$. maltophilia generated in these three analyses had a mean similarity index of 95\% with the profile in the MIS database, indicating the technical accuracy of these analyses (Table 2). The fatty acid profiles of the $24 X$. campestris pv. vitians strains had a mean similarity index of $70 \%$ (range of 42 to $88 \%$ ) with the $X$. campestris profile, consistent with these being strains of $X$. campestris. When the profiles of these strains were compared with those of $X$. campestris pathovars in the database, the closest matches were $X$. campestris pv. vitians (54\%), X. campestris pv. carotae (39\%), and X. campestris pv. pelargonii $(7 \%)$ (Table 2). Moreover, most strains were not consistently identified as a single pathovar, and the pathovar identified as being the closest match varied among replicates $(X$. campestris pv. vitians for replicates 1 and 2 , and $X$. campestris $\mathrm{pv}$. carotae for replicate 3 ; Table 2 ). Thus, the results of the fatty acid analyses indicated that the $X$. campestris pv. vitians strains were $X$. campestris, but did not consistently identify them as $X$. campestris pv. vitians or reveal distinct groups within the strains.

Rep-PCR. The patterns of DNA fragments (hereafter referred to as fingerprints) generated by rep-PCR for all pathogenic strains of $X$. campestris pv. vitians were indistinguishable, regardless of the primer used (REP, ERIC, or BOX). In contrast, rep-PCR DNA fingerprints of the nonpathogenic strains LMG 937 and LMG 8689 were different from each other and from the fingerprint of the $X$. campestris pv. vitians strains (Fig. 1). The rep-PCR fingerprint of $X$. campestris pv. vitians also was distinct from those of the other $X$. campestris pathovars (Fig. 2). These results indicate that the pathogenic $X$. campestris pv. vitians strains compose a relatively homogenous group, and that strains LMG 937 and LMG 8689 are genetically distinct.

PCR amplification and sequence analysis of the ITS1 region. The L1/G1 primer pair directs the amplification of the ITS1 sequence from a wide range of bacteria (15). This primer pair directed the amplification of an $\approx 600$-bp DNA fragment from genomic DNA of 14 strains of $X$. campestris pv. vitians (including the nonpathogenic LMG 937 and LMG 8689), 3 strains of $X$. campestris pv. carotae, and 2 strains each of $X$. campestris pv. phaseoli and X. campestris pv. phaseoli var. fuscans (Table 1).

TABLE 2. Results of fatty acid analyses of Xanthomonas campestris pv. vitians strains

\begin{tabular}{|c|c|c|c|c|c|c|}
\hline \multirow[b]{2}{*}{ Strains } & \multicolumn{2}{|c|}{ Replicate 1} & \multicolumn{2}{|c|}{ Replicate 2} & \multicolumn{2}{|c|}{ Replicate 3} \\
\hline & Pathovar $^{\mathrm{a}}$ & Sim. $^{b}$ & Pathovar & Sim. & Pathovar & Sim. \\
\hline Control & S. maltophilia & 0.926 & S. maltophilia & 0.965 & S. maltophilia & 0.962 \\
\hline Fl-1 & vitians & 0.552 & carotae & 0.667 & carotae & 0.722 \\
\hline 9301 & vitians & 0.843 & pelargonii & 0.420 & carotae & 0.654 \\
\hline 9302 & vitians & 0.882 & vitians & 0.773 & carotae & 0.788 \\
\hline 9303 & vitians & 0.573 & vitians & 0.605 & carotae & 0.654 \\
\hline 9304 & vitians & 0.887 & vitians & 0.666 & pelargonii & 0.467 \\
\hline 9305 & vitians & 0.743 & vitians & 0.766 & carotae & 0.785 \\
\hline 9306 & vitians & 0.722 & vitians & 0.654 & carotae & 0.737 \\
\hline 9307 & vitians & 0.641 & vitians & 0.830 & carotae & 0.728 \\
\hline 9308 & vitians & 0.674 & carotae & 0.574 & carotae & 0.735 \\
\hline 9309 & vitians & 0.843 & vitians & 0.809 & carotae & 0.767 \\
\hline 9310 & vitians & 0.850 & carotae & 0.740 & carotae & 0.774 \\
\hline $\mathrm{H}+$ & vitians & 0.612 & carotae & 0.745 & vitians & 0.787 \\
\hline 41335 & vitians & 0.428 & vitians & 0.789 & carotae & 0.720 \\
\hline 30547 & vitians & 0.590 & carotae & 0.693 & carotae & 0.758 \\
\hline 31975 & vitians & 0.701 & carotae & 0.717 & carotae & 0.739 \\
\hline 30526 & vitians & 0.592 & carotae & 0.743 & carotae & 0.724 \\
\hline $95-02$ & vitians & 0.729 & vitians & 0.743 & carotae & 0.761 \\
\hline Pyb251 & vitians & 0.700 & vitians & 0.679 & carotae & 0.789 \\
\hline Sal & carotae & 0.487 & carotae & 0.623 & vitians & 0.573 \\
\hline $\mathrm{KC}$ & vitians & 0.666 & vitians & 0.632 & carotae & 0.735 \\
\hline GON & vitians & 0.664 & vitians & 0.056 & vitians & 0.701 \\
\hline 9401 & vitians & 0.869 & vitians & 0.731 & carotae & 0.756 \\
\hline B 162 & vitians & 0.863 & carotae & 0.797 & vitians & 0.740 \\
\hline LL2 & pelargonii & 0.593 & pelargonii & 0.816 & pelargonii & 0.658 \\
\hline
\end{tabular}

${ }^{a} X$. campestris pathovar having the highest matching value for each strain for each replicate.

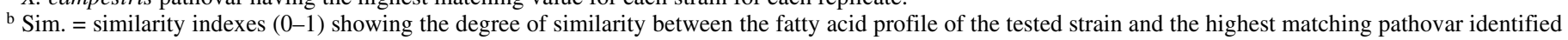
in the Microbial Identification System database. 
There were 554 nucleotide positions aligned as homologous character traits. A BLAST search of the EMBL/GenBank/DDBJ database conducted with the sequences of the PCR-amplified fragment from $X$. campestris pv. vitians strain Sal revealed a high degree of sequence identity (98 to $100 \%$ ) with previously determined ITS1 sequences of $X$. campestris pv. vitians (strain 700a, AF060176 and strain 701, AF060177). Comparisons then were made with the other $X$. campestris ITS1 sequences determined in this study. The ITS1 sequences of the 14 pathogenic strains of $X$. campestris pv. vitians were identical. The ITS1 sequence of $X y$ lella fastidiosa (ATCC 35879) was used as the out-group based upon results of a BLAST search showing that this was the most similar non-Xanthomonas sequence (data not shown).

Of these 554 nucleotide positions, 23 were informative. The heuristic search resulted in a singular most parsimonious tree having a length of 29 steps, consistency index of 0.83 , a retention index of 0.96 and a rescaled consistency index of 0.80 . A cladogram representing this tree is shown in Figure 3. The phylogenetic analysis infers strong support for four distinct distal clades defined on the cladogram as clade A, Xanthomonas campestris pv. vitians taxa; clade B, tritomy of $X$. campestris pv. carotae taxa; clade $\mathrm{C}$, LMG 8689 and LMG 937; and clade D, X. campestris pv. phaseoli $+X$. campestris pv. phaseoli var. fuscans taxa. Clade A, consisting of $X$. campestris pv. vitians taxa, has an $86 \%$ bootstrap and one synapomorphic site, a $\mathrm{G}>\mathrm{A}$ transition that differentiates it from its sister clade (B) that includes the $X$. campestris pv. carotae taxa. The clade that includes clades $\mathrm{A}+\mathrm{B}(X$. campestris $\mathrm{pv}$. vitians $+X$. campestris pv. carotae taxa) is supported by a $98 \%$ bootstrap and is differentiated completely from clade $\mathrm{C}$ by 10 unambiguous synapomorphic sites in their ITS1 nucleotide sequences. This very high number of evolutionary changes in the ITS1 sequences between clade $\mathrm{A}+\mathrm{B}$ and clade $\mathrm{C}$ provides overwhelming evidence of the phylogenetic distance between the $X$. campestris pv. vitians taxa examined here and LMG 8689 and LMG 937. This significant genetic difference discovered in this study is consistent with the LMG 8689 and LMG 937 being morphologically distinct from the $X$. campestris pv. vitians strains and

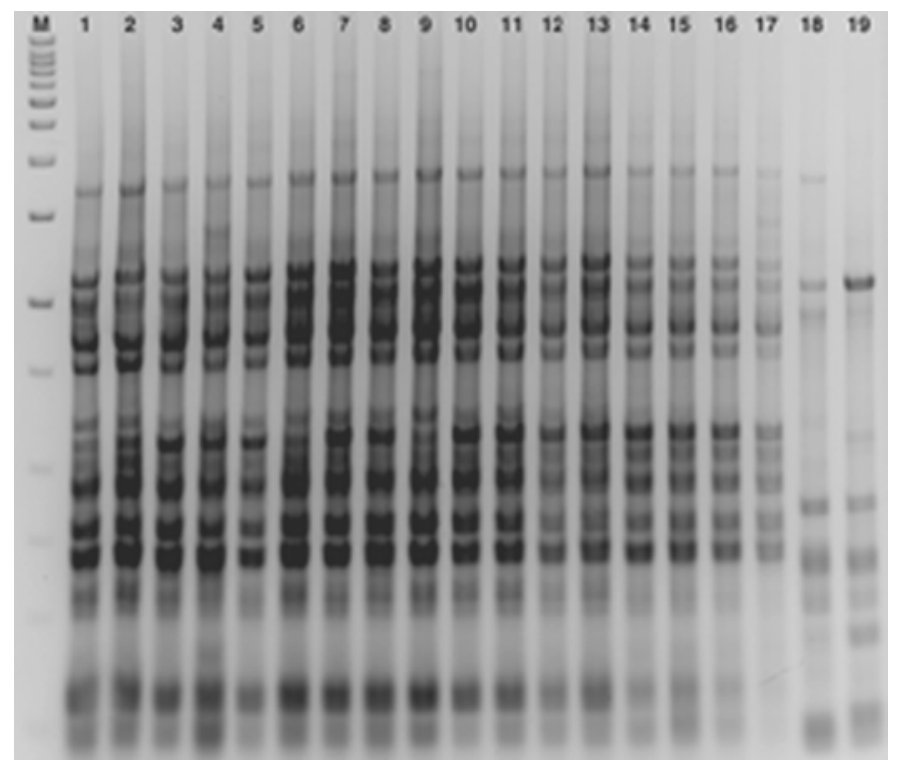

Fig. 1. Agarose gel showing polymerase chain reaction fingerprint patterns generated from genomic DNA from strains of various Xanthomonas campestris pathovars using primers corresponding to enterobacterial repetitive intergenic consensus sequences. Lane M contains DNA size markers (1-kb ladder, Gibco-BRL). Lane 1, strain 9834; lane 2, strain 9844; lane 3, strain 9851; lane 4, strain 9856; lane 5, strain 9862; lane 6, strain 9873; lane 7, strain 9906; lane 8, strain 9912; lane 9, strain 9915; lane 10, strain 9916; lane 11, strain B162; lane 12, strain LL2; lane 13, strain FL-1; lane 14, strain 9303; lane 15, strain 9308; lane 16, strain 41335; lane 17, strain 30526; lane 18, strain LMG 8689; and lane 19, strain LMG 937. their nonpathogenicity to lettuce. Clade D, consisting of X. campestris pv. phaseoli and $X$. campestris pv. phaseoli var. fuscans taxa, is the most basal clade and sister to all remaining $X$. campestris taxa analyzed. One synapomorphy within the ITS1 alignment, a $\mathrm{T}>\mathrm{C}$ transition, separates the $X$. campestris pv. phaseoli taxa from the $X$. campestris pv. phaseoli var. fuscans taxa. This genetic differentiation is consistent with the latter strains being phenotypically distinct from $X$. campestris pv. phaseoli by producing a brown melanin-like pigment in culture. In addition, clade $\mathrm{D}$ is supported by an $81 \%$ bootstrap, but, more significantly, is differentiated from the remaining $X$. campestris taxa by four synapomorphic sites within the ITS1 alignment.

RFLP analysis. RFLP analysis was performed with 17 strains of $X$. campestris pv. vitians from various geographical locations (Table 1). The $\mathrm{P} 2$ probe, which contains a repetitive element from the $X$. campestris pv. phaseoli genome (13), hybridized to multiple fragments of $X$. campestris pv. vitians total genomic DNA digested with EcoRI (Fig. 4), BamHI, or HincII. This indicates that repetitive DNA sequences are present in the $X$. campestris pv. vitians genome. No polymorphisms were observed among the strains of $X$. campestris pv. vitians when total genomic DNA was digested with BamHI (data not shown), whereas polymorphisms were detected when DNA was digested with EcoRI (Fig. 4) or HincII (data not shown). Strains from the same geographical location often had identical RFLP patterns (e.g., strains 9824, 9844, and 9856 from Santa Maria and Lompoc, CA; strains GON, 9306, and 9401 from Gonzales and Salinas, CA; and strains 9912 and 9916 from Hawaii) (Fig. 4 and data not shown). However, polymorphisms were detected among strains isolated during the same year from the same geographical location (e.g., strains 9862, 9868, and 9873 from Salinas) (Fig. 4). Thus, although strains from a given geographical area tended to have similar RFLP patterns, this was not always the case. This analysis also revealed that these $X$. campestris pv. vitians strains are not genetically identical (i.e., clonal).

Detection and analysis of plasmid DNA. Based on the number of bands observed in ethidium bromide-stained agarose gels, seven $X$. campestris pv. vitians strains had single plasmids, whereas two strains, B162 (isolated from Guadalupe, CA in 1995) and 31975 (isolated from Dareton, Australia in 1978) had two plasmids (Fig. 5A). When digested with EcoRI, BamHI, or SmaI, distinct banding patterns were detected for the single plasmids from strains Sal, LL2, 41335, 9824, and Fl-1, and for the two plasmids from strains B162 and 31975 (Fig. 5B). Similar banding patterns were obtained for plasmid DNAs from the two Hawaiian strains (9916 and 9912; Fig. 5B). Based upon the estimated fragment sizes for digested individual plasmids, the size of these plasmids ranged from 32 to $56 \mathrm{~kb}$.

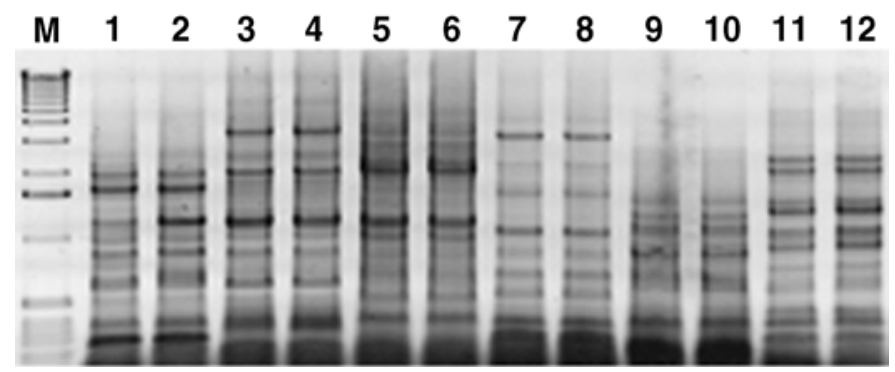

Fig. 2. Agarose gel showing polymerase chain reaction fingerprint patterns generated from genomic DNA from strains of various Xanthomonas campestris pathovars using primers corresponding to enterobacterial repetitive intergenic consensus sequences. Lane M contains DNA size markers (1-kb ladder, Gibco-BRL). Lanes 1 and 2, X. campestris pv. vitians (strains B162 and Sal); lanes 3 and 4, X. campestris pv. carotae (strains 9936 and 9940); lanes 5 and $6, X$. campestris pv. armoraciae (strains 275 and 756); lanes 7 and 8, X. campestris pv. alfalfae (strains 101 and 102); lanes 9 and 10, X. campestris pv. campestris (strains 295 and 404); and lanes 11 and 12, X. campestris pv. phaseoli var. fuscans (strains 54 and 13). 


\section{DISCUSSION}

The results of the various analyses of genetic diversity of $X$. campestris pv. vitians strains associated with recent BLS outbreaks in California and other geographical regions revealed that these strains compose a relatively homogeneous group, rather than being composed of genetically distinct strains. A number of $X$. campestris pathovars are heterogeneous (i.e., composed of genetically diverse strains) including pvs. begoniae (40), citri $(20,40)$, dieffenbachiae (4), hederae (24), mangiferaeindicae (11), and vesicatoria $(21,34)$. These are often pathovars with a relatively wide host range $(3,5,40)$. In most of these cases, the genetically diverse strains within a pathovar were readily identified by various genotypic and phenotypic criteria (5,20,21,24,34,39-41). Based on several of these criteria (e.g., pathogenicity, fatty acid profiles, rep-PCR, and ITS1 sequence analysis), genetically diverse strains were not detected among the pathogenic $X$. campestris pv. vitians strains examined in the present study. Thus, these results indicate that $X$. campestris pv. vitians is a homogeneous rather than heterogeneous pathovar. This also is con-

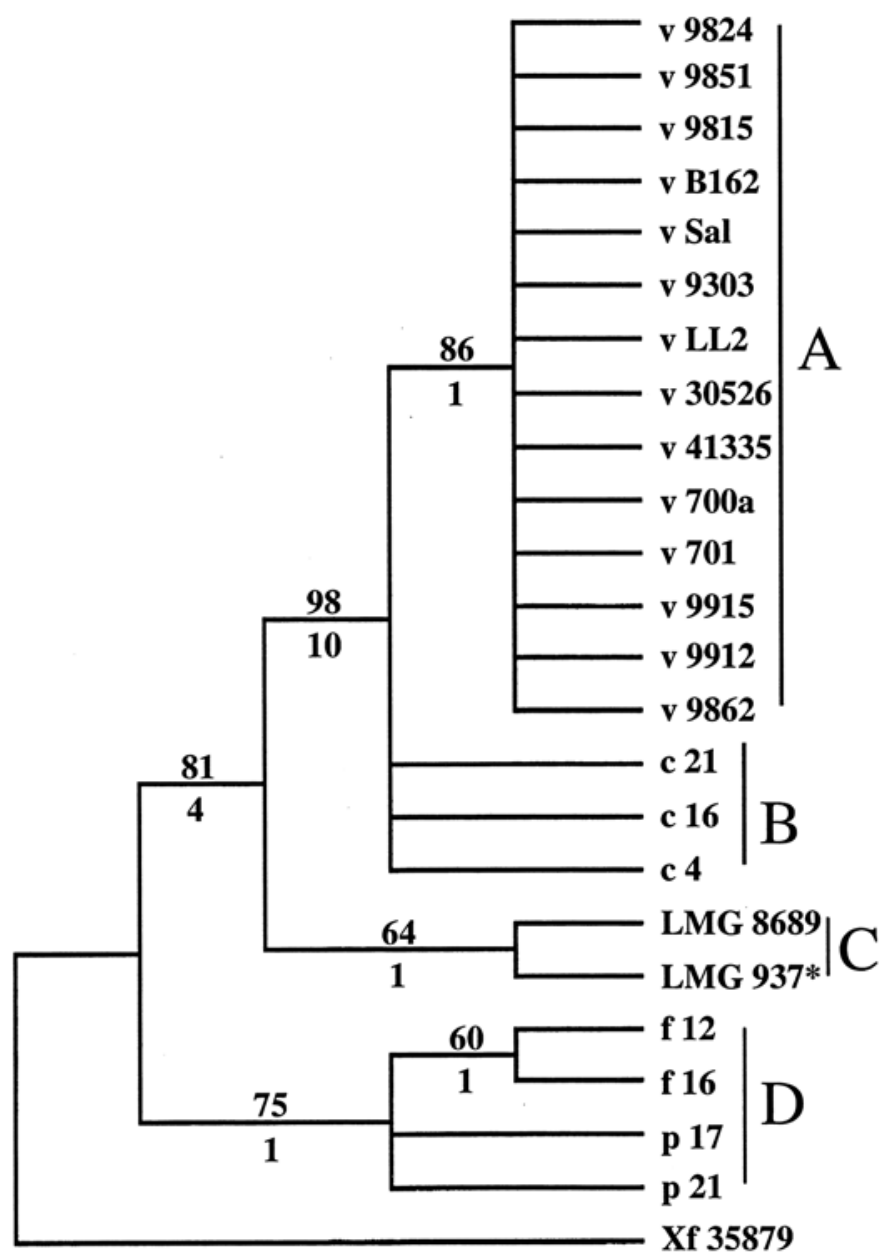

Fig. 3. Cladogram showing inferred evolutionary affiliations of 23 strains of Xanthomonas campestris pvs. vitians (v strains), carotae (c strains), phaseoli (p strains), and phaseoli var. fuscans (f strains), and Xylella fastidiosa (Xf; ATCC 35879). Cladogram is based on the singular most parsimonious tree resulting from a heuristic search (PAUP) on aligned internal transcribed spacer 1 nucleotide sequences. X. fastidiosa served as the outgroup taxon. Branch support is depicted in the cladogram as percent bootstrap support, numbers above branches, and number of unambiguous synapomorphic sites, numbers below branches. Analysis based on 23 informative characters out of 554 aligned characters. Tree statistics: TL, 29 steps; CI, 0.83; RI, 0.96; and $\mathrm{RC}=0.80$. The LMG 937 strain indicated with an asterisk is the type strain of Xanthomonas campestris pv. vitians.

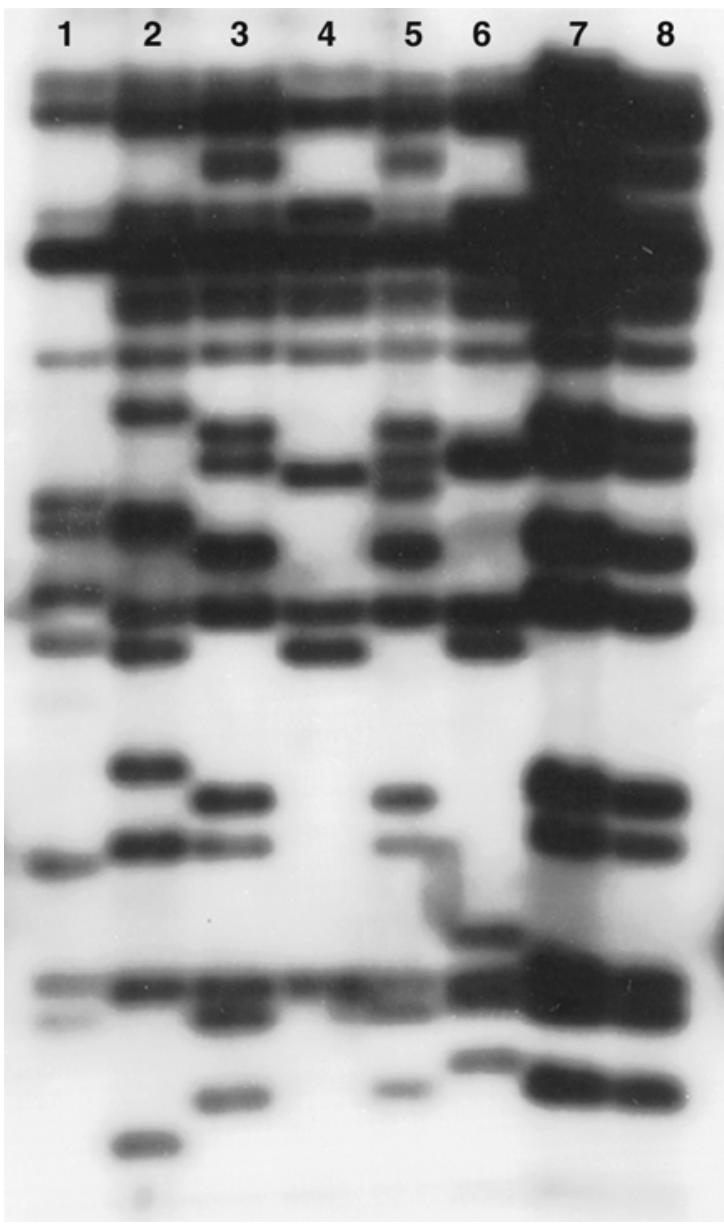

Fig. 4. Restriction fragment length polymorphism analysis of Xanthomonas campestris pv. vitians total genomic DNA digested with EcoRI and probed with recombinant plasmid $\mathrm{P} 2$, which contains an $X$. campestris pv. phaseoli genomic DNA fragment with a repetitive sequence. Lane 1, strain LL2; lane 2, strain B162; lane 3, strain 9862; lane 4, strain 9868; lane 5, strain 9873; lane 6, strain 9916; lane 7, strain 9824; and lane 8, strain 9856 .

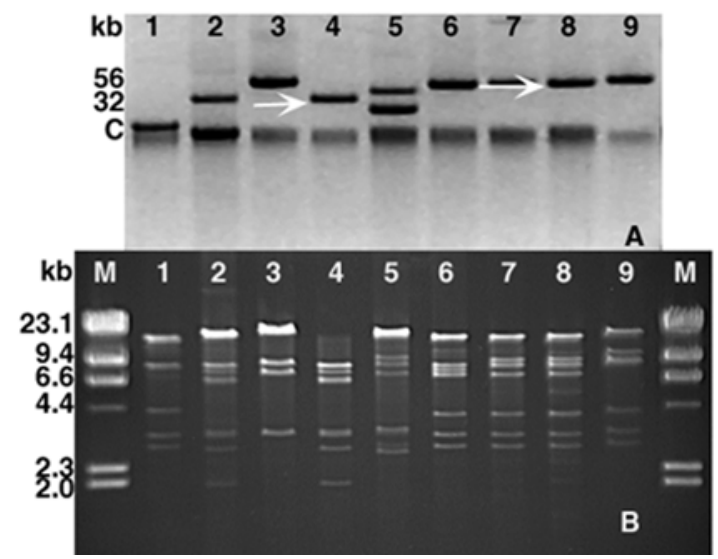

Fig. 5. Characterization of plasmid DNA extracted from strains of Xanthomonas campestris pv. vitians. A, Agarose gel showing plasmid DNA extracted from $X$. campestris pv. vitians. Arrows indicate the smallest (lane 4) and largest (lane 8) plasmids, and C indicates chromosomal DNA. Lane 1, strain Sal; lane 2, strain B162; lane 3, strain LL2; lane 4, strain 41335; lane 5, strain 31975; lane 6, strain 9824; lane 7, strain 9916; lane 8, strain 9912; and lane 9, strain Fl-1. B, Agarose gel showing plasmid DNA extracted from $X$. campestris pv. vitians digested with BamHI. Lanes M contains DNA size markers (Lambda DNA digested with HindIII); lane 1, strain Sal (Salinas, CA); lane 2, strain B162 (Guadalupe, CA); lane 3, strain LL2 (Bakersfield, CA); lane 4, strain 41335 (Australia); lane 5, strain 31975 (Dareton, Australia); lane 6, strain 9824 (Santa Maria, CA); lane 7, strain 9916 (Kula, HI); lane 8, strain 9912 (Kula, HI); and lane 9, strain Fl-1 (Florida). 
sistent with the fact that the host range of $X$. campestris pv. vitians is relatively narrow, including leaf and head lettuce types and a number of Lactuca spp. such as wild lettuce (L. serriola L.) $(14,18)$.

The rep-PCR analysis did not reveal differences among the $X$. campestris pv. vitians strains examined in this study, but did allow for differentiation of these strains from other $X$. campestris pathovars. These results provide further evidence that rep-PCR can be used to differentiate pathovars of $X$. campestris (20). For example, Louws et al. (20) found that the rep-PCR fingerprints of $X$. campestris pvs. campestris, phaseoli, pelargonii, and vesicatoria were distinct and distinguishable. Furthermore, rep-PCR analysis revealed intraspecific variability among strains of pathovars known to be heterogeneous (e.g., pvs. vesicatoria, citri, and campestris), but not among strains of pathovars considered to be more genetically homogeneous (e.g., pvs. phaseoli and pelarogonii). Thus, the finding that all pathogenic $X$. campestris pv. vitians strains had identical rep-PCR fingerprints is consistent with this being a homogeneous pathovar, as opposed to a limitation of the rep-PCR method to reveal genetic diversity within a pathovar. Recently, rep-PCR was used to differentiate strains of $X$. campestris pv. vitians from xanthomonad-like bacteria recovered from weeds around lettuce fields in California (1).

Analysis of ribosomal RNA is a well-established tool for revealing relationships among bacteria (42). Because of the high level of sequence conservation that can exist among rRNA genes $(16 \mathrm{~S}, 23 \mathrm{~S}$, and $5 \mathrm{~S})$ at the genus and species levels, the more variable sequences separating these genes (spacer regions) tend to be more useful for differentiating bacteria at these taxonomic levels (15). RFLP analysis of total genomic DNA of various $X$. campestris pathovars with a $16+23 \mathrm{~S}$ rRNA probe differentiated among pathovars and also revealed variability within certain pathovars (5). RFLP analysis of PCR-amplified $r r s$ (16S) and $r r l$ (23S) genes did not differentiate various pathovars of Pseudomonas syringae, whereas RFLP analysis of the ITS1 spacer region differentiated $P$. syringae pv. tomato strains from those of other pathovars (23). The ITS1 rDNA sequence was used recently as a diagnostic tool to help establish that a new disease of leek in California was caused by $P$. syringae pv. porri (17). The finding that the ITS1 sequences of the $X$. campestris pv. vitians strains were identical, but different from those of other pathovars, was further evidence of the genetic homogeneity of these strains and demonstrates the value of the ITS1 sequence as a diagnostic tool for identification of $X$. campestris pathovars.

The $X$. campestris pv. vitians strains examined in this study were not clonal because genetic diversity was detected by the RFLP and plasmid DNA analyses. The RFLP analysis was conducted with a repetitive DNA probe $(\mathrm{P} 2)$ from $X$. campestris pv. phaseoli, which has been used to differentiate strains of $X$. campestris pv. phaseoli from $X$. campestris pv. phaseoli var. fuscans, both of which cause common bacterial blight of bean, and to reveal polymorphisms among strains of $X$. campestris pv. phaseoli and $X$. campestris pv. phaseoli var. fuscans from different geographical locations (13). Hybridization of the P2 probe with multiple $X$. campestris pv. vitians restriction fragments indicates that a related repetitive element is present in the genome. Sequence analysis of the P2 probe has revealed a high level of sequence identity $(\approx 90 \%)$ to an insertion sequence identified in $X$. campestris pv. dieffenbachiae (4; data not shown). Thus, because these repetitive elements are likely to represent mobile genetic elements in genomic and plasmid DNA (7), it is not surprising that hybridization with such an element would reveal some level of diversity within strains of a homogeneous pathovar like $X$. campestris pv. vitians. Whereas most genetic diversity was detected among strains from different geographic regions, the finding of genetic diversity among some strains from the same location is consistent with localized evolution or multiple introductions via contaminated seed $(2,30)$.
During the course of this study, we did not find evidence that genetically distinct xanthomonads cause BLS of lettuce. The existence of genetically distinct strains of $X$. campestris pv. vitians initially was suggested based upon analyses of protein profiles; however, it is important to note that at least one of the aberrant strains (the pathovar reference strain NCPPB 976=LMG 937) was morphologically distinct and not pathogenic to lettuce (35). Furthermore, it was this strain that was found to be aberrant based on subsequent DNA-DNA hybridization and Biolog GN microplate fingerprint analyses, and used as the basis for proposing two new names for $X$. campestris pv. vitians: $X$. axonopodis pv. vitians and $X$. hortorum pv. vitians (37). Unfortunately, strains of $X$. axonopodis pv. vitians and $X$. hortorum pv. vitians obtained from Laboratorium voor Microbiologie Gent Culture Collection were not pathogenic to lettuce and were morphologically and genetically distinct from the pathogenic $X$. campestris pv. vitians strains used in the present study. Therefore, we were not able to confirm that genetically distinct xanthomonads cause BLS of lettuce. Recently, Schaad et al. (32) rejected the reclassification of $X$. campestris pv. vitians type $\mathrm{A}$ as $X$. axonopodis $\mathrm{pv}$. vitians and $X$. campestris $\mathrm{pv}$. vitians type B as $X$. hortorum pv. vitians, and recommended that all $X$. campestris strains pathogenic to lettuce be retained as $X$. campestris pv. vitians until additional phylogenetic information is available. Our results support those recommendations and also demonstrate the need to confirm the pathogenicity of strains used in phylogenetic and taxonomic studies. On the other hand, it is impossible to exclude the possibility that genetically distinct xanthomonads cause BLS of lettuce.

Crosse (8) and Schroth (33) stressed the importance of knowing the genetic diversity of a pathogen population occurring on a given host in a given locality, and the similarity or differences to other populations occurring on the same host in other localities. They warned of the possible inaccurate representation of an organism as it occurs in nature if studies are confined to only a few strains. The molecular tools used in this study offer a precise and reliable approach for analyzing the genetic diversity of bacterial strains involved with disease outbreaks at a local, regional, or even global scale. In the case of $X$. campestris pv. vitians, it seems that a few representative strains could be selected for epidemiological and taxonomic studies, as well for the identification of lettuce cultivars with BLS resistance.

\section{ACKNOWLEDGMENTS}

This work was partially supported by grants from the California Lettuce Research Board. We thank P. Guzmán and B. Kirkpatrick for providing technical advice, S. Koike and F. Laemmlen for help in collecting lettuce and weed samples for isolation of $X$. campestris pv. vitians, and A. Alvarez for providing $X$. campestris pv. vitians strains from Hawaii.

\section{LITERATURE CITED}

1. Barak, J. D., Koike, S. T., and Gilbertson, R. L. 2001. Survival of Xanthomonas campestris pv. vitians in association with crop debris and weeds. Plant Dis. 85:169-178.

2. Barak, J. D., Koike, S. T., and Gilbertson, R. L. 2002. Movement of Xanthomonas campestris pv. vitians in the stems of lettuce and seed contamination. Plant Pathol. 51:506-512.

3. Benedict, A. A., Alvarez, A. M., and Pollard, L. W. 1990. Pathovar-specific antigens of Xanthomonas campestris pv. pelarogonii detected with monoclonal antibodies. Appl. Environ. Microbiol. 56:572-574.

4. Berthier, Y., Thierry, D., Lemattre, M., and Guesdon, J. L. 1994. Isolation of an insertion sequence (IS1051) from Xanthomonas campestris pv. dieffenbachiae with potential use for strain identification and characterization. Appl. Environ. Microbiol. 60:377-384.

5. Berthier, Y., Verdier, V., Guesdon, J., Chevrier, D., Denis, J., Decoux, G., and Lemattre, M. 1993. Characterization of Xanthomonas campestris pathovars by rRNA gene restriction patterns. Appl. Environ. Microbiol. 59:851-859.

6. Carisse, O., Ouimet, A., and Toussaint, V. 2000. Evaluation of the effect of seed treatments, bactericides, and cultivars on bacterial leaf spot of 
lettuce caused by Xanthomonas campestris pv. vitians. Plant Dis. 84:295-299.

7. Chen, J. H., Hsieh, Y. Y., Hsiau, S. L., Lo, T. C., and Shau, C. C. 1999. Characterization of insertions of IS476 and two newly identified insertion sequences, IS1478 and IS1479, in Xanthomonas campestris pv. campestris. J. Bacteriol. 181:1220-1228.

8. Crosse, J. E. 1966. Epidemiological relations of the pseudomonad pathogens of deciduous fruit trees. Annu. Rev. Phytopathol. 27:187-212.

9. Daboin, C., and Tortolero, O. 1993. Bacterial leaf spot of lettuce in some fields of the Venezuelan Andes. Fitopatol. Venezolana 6:8-10.

10. Devereux, J., Haeberli, P., and Smithies, O. 1984. A comprehensive set of sequence analysis programs for the VAX. Nucleic Acids Res. 12:387395.

11. Gagnevin, L., Leach, J. E., and Pruvost, O. 1997. Genomic variability of the Xanthomonas pathovar mangiferaeindicae agent of mango bacterial black spot. Appl. Environ. Microbiol. 63:246-253.

12. Gilbertson, R. L., Maxwell, D. P., Hagedorn, D. J., and Leong, S. A. 1989. Development and application of a plasmid DNA probe for detection of bacteria causing common bacterial blight of bean. Phytopathology 79:518-525.

13. Gilbertson, R. L., Otoya, M. M., Pastor-Corrales, M. A., and Maxwell, D. P. 1991. Genetic diversity in common blight bacteria is revealed by cloned repetitive DNA sequences. Annu. Rep. Bean. Improv. Coop. 34:37-38.

14. Harrison, D. E. 1963. Leaf spot and dry rot of lettuce caused by Xanthomonas vitians (Brown) Dowson. Aust. J. Agric. Res. 14:778-784.

15. Jensen, M. A., Webster, J. A., and Straus, N. 1993. Rapid identification of bacteria on the basis of polymerase chain reaction-amplified ribosomal DNA spacer polymorphisms. Appl. Environ. Microbiol. 59:945952.

16. Kado, C. I., and Heskett, M. G. 1970. Selective media for isolation of Agrobacterium, Corynebacterium, Erwinia, Pseudomonas, and Xanthomonas. Phytopathology 60:969-976.

17. Koike, S. T., Barak, J. D., Henderson, D. M., and Gilbertson, R. L. 1999. Bacterial blight of leek: A new disease in California caused by Pseudomonas syringae. Plant Dis. 83:165-170.

18. Koike, S. T., and Gilbertson, R. L. 1997. Bacterial leafspot of lettuce. In: Compendium of Lettuce Diseases. R. M. Davis, K. V. Subbarao, R. N. Raid, and E. A. Kurtz, eds. The American Phytopathological Society, St. Paul, MN

19. Lipp, R. L., Alvarez, A. M., Benedict, A. A., and Berestecky, J. 1992. Use of monoclonal antibodies and pathogenicity tests to characterize strains of Xanthomonas campestris pv. dieffenbachiae from aroids. Phytopathology 82:677-682.

20. Louws, F. J., Fulbright, D. W., Stephens, C. T., and deBruijn, F. J. 1994. Specific genomic fingerprints of phytopathogenic Xanthomonas and Pseudomonas pathovars and strains generated with repetitive sequences and PCR. Appl. Environ. Microbiol. 60:2286-2295.

21. Louws, F. J., Fulbright, D. W., Stephens, C. T., and de Bruijn, F. J. 1995. Differentiation of genomic structure by rep-PCR fingerprinting to rapidly classify Xanthomonas campestris pv. vesicatoria. Phytopathology 85:528-536.

22. Maddison, W. P., and Maddison, D. R. 1992. MacClade Version 3.05. Sinauer Associates, Sunderland, MA.

23. Manceau, C., and Horvais, A. 1997. Assessment of genetic diversity among strains of Pseudomonas syringae by PCR-restriction fragment length polymorphism analysis of rRNA operons with special emphasis on P. syringae pv. tomato. Appl. Environ. Microbiol. 63:498-505.

24. Norman, D. J., Chase, A. R., Stall, R. E., and Jones, J. B. 1999. Heterogeneity of Xanthomonas campestris pv. hederae strains from araliaceous hosts. Phytopathology 89:646-652.
25. Ouvrard, D., Campbell, B. C., Bourgoin, T., and Chan, K. 2000. $18 \mathrm{~S}$ rRNA secondary structure and phylogenetic position of Peloridiidae (Insecta, Hemiptera). Mol. Phylogenet. Evol. 16:403-417.

26. Paisley, R. 1995. Pages M-5 in: MIS Whole Cell Fatty Acid Analysis by Gas Chromatography. MIDI, Inc., Newark, DE

27. Pernezny, K., Raid, R. N., Stall, R. E., Hodge, N. C., and Collins, J. 1995. An outbreak of bacterial spot of lettuce in Florida caused by Xanthomonas campestris pv. vitians. Plant Dis. 79:359-360.

28. Rademaker, J. L. W., and de Bruijn, F. J. 1997. Characterization and classification of microbes by rep-PCR genomic fingerprinting and computer assisted pattern analysis. Pages 151-171 in: DNA Markers: Protocols, Applications and Overviews. B. Caetano-Anolles and P. M. Gresshoff, eds. John Wiley \& Sons, New York.

29. Sahin, F. 2000. First report of bacterial spot of lettuce caused by Xanthomonas campestris pv. vitians in Turkey. Plant Dis. 84:490.

30. Sahin, F., and Miller, S. A. 1997. Identification of the bacterial leaf spot pathogen of lettuce, Xanthomonas campestris pv. vitians, in Ohio, and assessment of cultivar resistance and seed treatment. Plant Dis. 81:14431446.

31. Sambrook, J., Fritsch, E. F., and Maniatis, T. 1989. Molecular Cloning: A Laboratory Manual. 2nd ed. Cold Spring Harbor Laboratory, Cold Spring Harbor, NY.

32. Schaad, N. W., Vidaver, A. K., Lacy, G. H., Rudolph, K., and Jones, J. B. 2000. Evaluation of proposed amended names of several Pseudomonads and Xanthomonads and recommendations. Phytopathology 90:208-213.

33. Schroth, M. N. 1968. Comments on the paper of Colwell et al., Computer analysis of relationships among phytopathogenic bacteria. Phytopathology 58:1216-1217.

34. Stall, R. E., Beaulieu, C., Egel, D., Hodge, N. C., Leite, R. P., Minsavage, G. V., Bouzar, H., Jones, J. B., Alvarez, A. M., and Benedict, A. A. 1994. Two genetically diverse groups of strains are included in Xanthomonas campestris pv. vesicatoria. Int. J. Syst. Bacteriol. 44:4753.

35. Stefani, E., Raio, A., Bazzi, C., and Zoina, A. 1994. Identification and grouping of Xanthomonas campestris pv. vitians using SDS-PAGE. Phytopathol. Mediterr. 33:99-104.

36. Swofford, D. L. 2002. PAUP. Phylogenetic Analysis Using Parsimony. Version 4. Sinauer Associates, Sunderland, MA.

37. Vauterin, L., Hoste, B., Kesters, K., and Swings, J. 1995. Reclassification of Xanthomonas. Int. J. Syst. Bacteriol. 45:472-489.

38. Vauterin, L., Rademaker, J., and Swings, J. 2000. Synopsis on the taxonomy of the genus Xanthomonas. Phytopathology 90:677-682.

39. Vauterin, L., Swings, J., and Kersters, K. 1991. Grouping of Xanthomonas campestris pathovars by SDS-PAGE of proteins. J. Gen. Microbiol. 137:1677-1687.

40. Vauterin, L., Vantomme, R., Pot, B., Hoste, B., Swings, J., and Kersters, K. 1990. Taxonomic analysis of Xanthomonas campestris pv. begoniae and $X$. campestris pv. pelargonii by means of phytopathological, phenotypic, protein electrophoretic and DNA hybridization methods. Syst. Appl. Microbiol. 13:166-176.

41. Vauterin, L., Yang, P., Hoste, B., Vancanneyt, Civerolo, E. L., Swings, J., and Kersters, K. 1991. Differentiation of Xanthomonas campestris pv. Citri strains by sodium dodecyl sulfate-polyacrylamide gel electrophoresis of proteins, fatty acid analysis and DNA-DNA hybridization. Int. J. Syst. Bacteriol. 41:535-542.

42. Woese, C. R. 1987. Bacterial evolution. Microbiol. Rev. 51:221-271.

43. Zoina, A., and Volpe, E. 1994. Epidemiological aspects of lettuce bacterial spot induced by Xanthomonas campestris pv. vitians. Pages 797802 in: Plant-Pathogenic Bacteria. M. Lemattre, S. Freigoun, K. Rudolph, and J. G. Swings, eds. INRA Colloquia,Versailles, France. 